\title{
ECOLOGY OF THE ACALYPTA SPECIES OCCURRING IN HUNGARY (INSECTA: HETEROPTERA: TINGIDAE) DATA TO THE KNOWLEDGE ON THE GROUND-LIVING HETEROPTERA OF HUNGARY, № 3.
}

\author{
D. RÉDEI ${ }^{1} *$ - B. HARMAT ${ }^{2}-$ L. HUFNAGEL ${ }^{3}$ \\ *e-mail:dredei@freemail.hu \\ ${ }^{1}$ Department of Entomology, Corvinus University of Budapest, \\ H-1118 Budapest, Ménesi út 44, Hungary \\ (*phone / fax: +36-1-372-0125) \\ ${ }^{2}$ Natural History Museum of Bakony Mountains, \\ H-8420 Zirc, Rákóczi tér 1., Hungary \\ ${ }^{3}$ Department of Mathematics and Informatics, Corvinus University of Budapest, \\ H-1118 Budapest, Villányi út 29-33, Hungary \\ (Received $4^{\text {th }}$ August 2004; accepted $22^{\text {nd }}$ October 2004)
}

\begin{abstract}
As a third part of a series of papers on the ground-living true bugs of Hungary, the species belonging to the lace bug genus Acalypta Westwood, 1840 (Insecta: Heteroptera: Tingidae) were studied. Extensive materials collected with Berlese funnels during about 20 years all over Hungary were identified. Based on these sporadic data of many years, faunistic notes are given on some Hungarian species. The seasonal occurrence of the species are discussed. The numbers of specimens of different Acalypta species collected in diverse plant communities are compared with multivariate methods. Materials collected with pitfall traps between 1979-1982 at Bugac, Kiskunság National Park were also processed. In this area, only $A$. marginata and A. gracilis occurred, both in great number. The temporal changes of the populations are discussed. Significant differences could be observed between the microhabitat distribution of the two species: both species occurred in very low number in traps placed out in patches colonized by dune-slack purple moorgrass meadow; Acalypta gracilis preferred distinctly the Pannonic dune open grassland patches; A. marginata occurred in almost equal number in Pannonic dune open grassland and in Pannonic sand puszta patches.
\end{abstract}

Keywords. Heteroptera, Tingidae, Acalypta, phenology, habitat preference, microhabitats

\section{Introduction}

The lace bug genus Acalypta Westwood, 1840 is widely distributed in the temperate areas of the Northern Hemisphere and contains approximately 30 described species. The species belonging to the genus are primarily muscicolous, however some of them can also be observed on the stems of diverse plants. Much information are available on the ecological preferences of the common European species, based mostly on many years of field experience of heteropterists. However, quantitative data on the dynamics of the population and the preferences of the species are very rare.

As a third part of this series of publication on the Heteroptera occurring at the ground level in Hungary, in order to compare the habitat preferences of the Hungarian Acalypta species, the authors examined extensive materials of Acalypta collected with Berlese funnels during about 20 years all over Hungary. Because of the identical way of collecting, the samples can be well used for the characterization of the species and also 
the habitats. The substrate preferences of the species as well as the seasonal changes of occurrence of the species were examined. Furthermore, the data of the numerous Acalypta specimens collected with pitfall traps between 1979-1982 at Bugac, Kiskunság National Park were also processed. The temporal changes of the populations and the microhabitat preference of the species were compared.

\section{Review of literature}

Out of the 18 species of Acalypta occurring in Europe [26, 27], the occurrence of 8 species were reported from Hungary [21].

After Butler's classic work [7], it was V.G. Putshkov [30] who summarized our knowledge on the biology of a part of the European species of Tingidae and he also presented numerous original data and observations. Later, Péricart [26] published a monograph on the Euro-Mediterranean lace bugs. In this work, he also synthetized the data available on the ecology of each species discussed. The Hungarian species were keyed and their biology and distribution briefly discussed by Vásárhelyi [49]. The latest Hungarian check-list was compiled by Kondorosy [21].

According to the literature, the species of the genus live primarily in mosses or Sphagnums and probably they also feed on these. Many authors observed them on the stems of short plants (see below); however, their trophic relations to these plants are very improbable [26, 30]. Most species occurring in Hungary most probably overwinter as adults or elder larvae $[26,30]$.

Acalypta carinata (Panzer, 1806), a Eurosiberian species, was reported from Sphagnums or other mosses - e.g., Abietinella abietina (Hedw.) Fleisch. [36] - growing on the ground, tree trunks etc. Typically, it prefers humid, shady, mostly woodland habitats $[4,26,30,37]$; it was found in deciduous as well as in coniferous forests [37]. It can be collected throughout the year, oviposition in September, adults or elder larvae overwinter $[30,35]$. In Hungary, for a long time the species was recorded only from a single locality [16]. Later it was found in the Bátorliget Nature Reserves [48], where several specimens were captured with pitfall trap and by sifting [50]. Recently, numerous new localities were reported [32]. The species must be relatively frequent in suitable places.

Acalypta platycheila (Fieber, 1844) is a closely related and very similar species to $A$. carinata, therefore, probably it also has similar life habits. However, the comparison of the ecological preferences of the two species based on literature data is impossible because of the numerous misidentifications [26]. In the Ukraine, it was collected among Pleurozium schreberi (Brid.) Mitt. growing on meadows and clearings [36]. Only a few specimens have hitherto been reported from Hungary [2, 32, 48, 49, 50]. Probably it occurs sporadically all over the country but it seems to be rare everywhere.

Acalypta nigrina (Fallén, 1807), a Eurosiberian species with boreo-alpine distribution, was collected among mosses - Hylocomium splendens (Hedw.) B.S.G., Polytrichum sp. [36] -, on the stems of short plants (Calluna, Hieracium, Thymus etc.) and also under stones [26]. It is known to be far less hygrophilous than the previous two species (also reported from dry sandy grasslands [13]), preferring also grassland and woodland habitats $[4,7,12,26,30,38]$. It was recorded occurring together with $A$. marginata [30], A. parvula [24] or both [14]. It is univoltine in Northwestern Germany, copulation and oviposition take place in June-July and July-August, respectively [24]; adults and elder larvae 
overwinter $[24,26,30]$. Only three places of collection in Hungary have hitherto been published [3, 13, 32, 48, 49]; it is one of the rarest Acalypta species in Hungary.

Acalypta marginata (Wolff, 1804), a Eurosiberian species, was observed to occur on the stems of diverse plants (Artemisia, Calluna, Hieracium, Thymus) by many authors; however, its trophic relations to these plants need verification [26, 30, 39]. It was found also in mosses (e.g. Rhytidiadelphus sp. [36]). It was captured in diverse biotopes, primarily in relatively dry ones $[11,37,19]$ (in large numbers in dry sandy grasslands [13]), but also in humid places, even in swamps $[4,18,19]$. It can be collected throughout the year, oviposite in moss and also in detritus, adults or elder larvae overwinter [30]. In Hungary it is not frequent but occurs sporadically all over the country [49].

Acalypta parvula (Fallén, 1807) is a West-Palaearctic species also occurring in the Nearctic Region. It occurs in mosses and also on the stems of different plants (Calluna, Genista, Thymus, Ulex) and even on fungi. It can be found in diverse biotopes [37]; it seems to prefer relatively dry ones, but was also recorded from humid places $[18,26]$. It is univoltine in Northwestern Germany, copulation and oviposition take place in AugustSeptember and September-October, respectively [24]; adults and eggs [24] or adults and elder larvae [26] overwinter. Jordan [19] mentioned it as the most common species in the former DDR. According to Vásárhelyi [48, 49], it is rare in Hungary, known only from a few places; however, a great number of localities were published recently [32].

Acalypta gracilis (Fieber, 1844), a Eurosiberian species, was reported from different mosses, e.g. Pleurozium schreberi (Brid.) Mitt., Ptilium crista-castrensis (Hedw.) De Not., Tortula ruralis (Hedw.) Gaertn. et al. [26, 30, 36]. It was been observed occurring on the stems of diverse plants (Ajuga, Alkanna, Artemisia, Dianthus, Erodium, Hieracium, Plantago, Sedum, Thymus) [3, 26]. It seems to occur primarily in relatively dry, sunny biotopes (e.g. dry sandy grasslands [13]), but it tolerates diverse habitats (forests, steep banks of rivers etc. [30]). Adults or elder larvae overwinter [26, 30]. Several localities are known from Hungary, mainly from the Great Hungarian Plain (Alföld) [2, 3, 13, 32, 49]; however, it seems to be not common, but locally frequent.

Acalypta musci (Schrank, 1781), a European species, occurs primarily in different mosses - Abietinella abietina (Hedw.) Fleisch., Plagiomnium cuspidatum (Hedw.) Kop., P. undulatum (Hedw.) Kop. [30,36] -, but was also found on fungi growing on tree trunks (Coriolus, Polyporus, Trametes) [39, 44]. It seems to prefer highlands and was recorded to occur primarily in woodland habitats [26, 41]. It is mentioned in the literature as a species occurring in relatively humid places [4], frequently in mosses growing at the foot of trees $[19,37,52]$. Adults and nymphs can be found together throughout the year [26, 30, 35]. The species is frequent in Hungary [32, 49].

Acalypta pulchra Štusák, 1961 was reported to occur in Austria, Bulgaria and the former Yugoslavia. In the literature the species is also mentioned from Hungary [26, 27]. These records are based on Puton's historical collection - deposited in the Muséum National d'Histoire Naturelle, Paris -, in which there are four specimens labelled „Hongrie" [26]. However, these specimens were collected very probably on locality or localities today not belonging to Hungary. No other found of this species has hitherto been reported. In the latest check-list of the Heteroptera of Hungary, A. pulchra is also included [21], but the author only cited Péricart's work mentioned above, without seeing voucher specimens (Kondorosy, pers. comm.). Therefore, the occurrence of the species in Hungary needs verification. Practically nothing is known on its life habits.

Quantitative data on the dynamics of population and the preferences of Acalypta species were not published except Melber's paper [24] in which the author gave very 
detailed data on the seasonal and microhabitat distribution of two syntopic species, $A$. nigrina and A. parvula, based on examinations in Northwestern Germany. In this study, A. nigrina was observed to prefer grounds densely covered by Calluna vulgaris (L.) Hull., while A parvula occurred mostly in open and half-open places, most probably because of their different preference of humidity.

\section{Materials and methods}

The investigations were carried out on two materials:

\section{Materials extracted with Berlese-funnels throughout Hungary}

Material collected by the staff of the Department of Systematic Zoology and Ecology of Eötvös Loránd University, under the guidance of the late Dr. I. Loksa, between 1953-1974. The material was extracted with Berlese funnels from different substrata collected in all regions of Hungary (altogether 3657 samples). The materials were identified by D. Rédei (see also [31, 32]).

\section{Materials taken by pitfall traps in the Kiskunság National Park}

Material collected by the staff of the Department of Ecology of the University of Szeged under the leading of L. Gallé, Gy. Györffy, E. Hornung and L. Móczár between 1979-1982 with pitfall traps at Bugac, in the Kiskunság National Park. The research was carried out within the frame of the international program „Man And Biosphere” (MAB) [25].

The investigated area, mapped in Figs. 1-2, was not grazed at all after 1976, therefore, its vegetation is nearly natural, composed of a mosaic combination of the following plant communities developed on the topographically and microclimatically different patches of the moving sand $[5,9,23]$ :

1. Festucetum vaginatae Rapaics ex Soó 1929 em. Borhidi 1996 (= festucetosum vaginatae seu typicum) - Pannonic dune open grassland. One of the most widely distributed endemic plant communities in Hungary. It can be found in many places in the sandy areas of the Great Hungarian Plain, most typical representatives in the area between the rivers Danube and Tisza [6]. In the areas at Bócsa and Bugac, in the Kiskunság National Park, almost native stands occur. It colonizes the thermic slopes and tops of dunes and constitutes the most widely occurring community in the investigated area. Its soil is characterized by very low water $(2-7 \%)$ and humus $(<1.5 \%)$ content [22].

2. Potentillo arenariae-Festucetum pseudovinae Soó (1938) 1940 - Pannonic sand puszta. Short, closed fescue pastures of sandy alluvial soils of the Pannonic basin, formerly widely distributed in the Hungarian plains, nowadays only local stands remained [6]. In the investigated area it occupies an intermediate position between Pannonic dune open grassland and dune-slack purple moorgrass meadow patches; as regards the water and humus content of soil, it is similar to the latter one [22].

3. Molinio-Salicetum rosmarinifoliae Magyar ex Soó 1933 - dune-slack purple moorgrass meadow. Pioneer grassland of Pannonic sands characterized by the juxtaposition of hygrophilous and xerophilous plant species. Occurs sporadically in the Great Hungarian Plain [6]. It colonizes the somewhat water-retentive depressions between dunes in the investigated area. Compared to Pannonic dune open grassland, its soil is characterized by relatively high water (3-15\%) and humus (about 3.5\%) content [22]. 
In the investigated area, the fauna was examined by diverse methods. The most extensively used method was pitfall trapping; the data of these were processed in course of the present study. The traps were placed out in 14-18 groups, each containing five of them. Traps were emptied and reset usually every month in 1979, every two weeks from 1980, between early spring and late autumn.

In order to establish the period of oviposition, the degree of maturity of the ovaria of females was investigated by dissection.

The materials were identified and preliminary faunistical data of the Heteroptera captured during the investigations were published by B. Harmat [13].
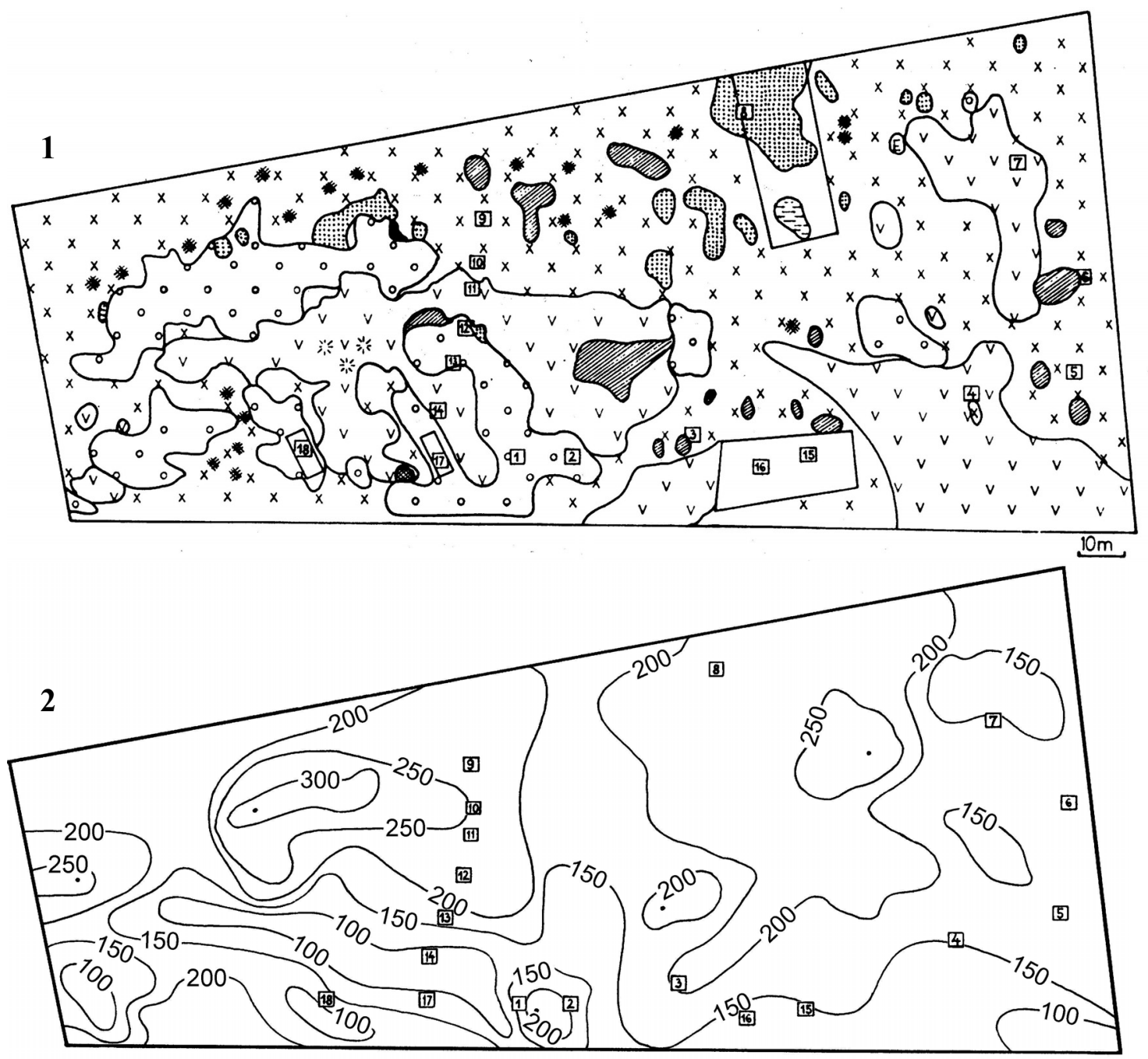

Figures 1-2. The vegetation (Fig. 1) and relief (Fig. 2) of the examined area (Bugac). 0 = Festucetum vaginatae; $\boldsymbol{\nabla}=$ Molinio-Salicetum rosmarinifoliae; $\boldsymbol{\bigotimes}=$ Potentillo-Festucetum pseudovinae; = Carex; $\mathbf{Z}=$ Stipetosum capillatae; $=$ Holoschoenus romanus; $\mathbf{\square}=$ Sedum; 圆=Brometum Secale facies; $\mathbf{E}=$ Euphorbia segueriana; 泣= Salix; 团...= No. of sampling site.

For the identification of adults, Vásárhelyi's [49], Wagner's [52] and Péricart's [26] works, of larvae Péricart's [26] monograph and Štusák's papers [40, 42, 43] were used. For distinguishing A. carinata and A. platycheila, the paper of Golub \& Péricart [10] was also consulted. The nomenclature follows the Catalogue of the Heteroptera of the Palaearctic Region [27]. 
For the multivariate data analysis the program package SYN-TAX $5.1[28,29]$ was used. The diversity ordering was carried out with the program package NuCoSA 1.05 $[45,46,47]$.

\section{Results and discussion}

\section{Materials extracted with Berlese-funnels throughout Hungary}

\section{Species composition}

A total number of 2542 specimens belonging to the genus Acalypta was found in the materials extracted with Berlese funnels. Each species recorded from Hungary before have been found except of $A$. pulchra, which occurrence is quite doubtful. The majority $(74.4 \%)$ of the extracted specimens are larvae (Table 1 ).

Table 1. The number of Acalypta specimens extracted with Berlese funnels. L1 ..L5 $=1^{\text {st } \ldots 5^{\text {th }}}$ instar larvae.

\begin{tabular}{l|cccccc|c}
\hline \multicolumn{1}{c|}{ Species } & adult & L5 & L4 & L3 & L2 & L1 & altogether \\
\hline Acalypta carinata (Panzer, 1806) & 66 & 390 & 141 & 47 & 19 & - & 663 \\
Acalypta platycheila (Fieber, 1844) & 11 & - & - & - & - & - & 11 \\
Acalypta nigrina (Fallén, 1807) & 5 & - & - & - & - & - & 5 \\
Acalypta marginata (Wolff, 1804) & 54 & 193 & 48 & 21 & 17 & 14 & 347 \\
Acalypta parvula (Fallén 1807) & 145 & 20 & 2 & 2 & - & - & 169 \\
Acalypta gracilis (Fieber, 1844) & 13 & 32 & 8 & - & - & - & 53 \\
Acalypta musci (Schrank, 1781) & 358 & 154 & 341 & 314 & 126 & 1 & 1294 \\
\hline
\end{tabular}

\section{Faunistical notes}

A considerable part of the faunistical data of Loksa's pitfall trap material was published in different papers [1, 33, 34].

A list of the localities where samples were collected for extracting was published in the first part of this series of publications [32]. However, that paper contained only the data of the adult Acalypta specimens. In addition, a list of localities where larvae were found is given below. The names of species are followed by the recorded localities and their UTM codes in square brackets.

Acalypta carinata (Panzer, 1806): Alsópetény [CU60], Alsószuha [DU65], Ásotthalom [DS01], Bak [XM47], Balástya [DS24], Böhönye [XM84], Csaroda [FU03], Csongrád [DS37], Csöde [XM18], Fülöpháza [CS89], Gulács [FU02], Jánd [FU03], Kelebia [CS91], Kékkút [XM99], Marcali [XM86], Mátraszőlős [CU91], Mesztegnyő [XM85], Nagybajom [XM94], Nemesvid [XM75], Somogyaszaló [YM14], Somogytúr [YM17], Szendehely [CU50], Szenyér [XM84], Tiszaalpár [DS28], Vámosatya [FU03], Vindornyaszőlös [XM69]. - The species was rarely collected in Hungary before. However, a great number of it were collected by Loksa. The localities of the species in Hungary are depicted in Fig. 3.

Acalypta marginata (Wolff, 1804): Alsószuha [DU65], Ásotthalom [DS01], Balatonalmádi [BT71], Bélapátfalva [DU52], Bódvarákó [DU87], Csákvár [CT05], Csöde [XM18], Csővár [CT79], Esztergom [CT39], Fenyőfö [YN04], Harka [XN27], Jánd [FU03], Jósvafö [DU67], Kelebia [CS91], Kesztölc [CT38], Kosd [CT69], Kunbaracs [CT70], Mátraszőlös [CU91], Mesztegnyő [XM85], Nagykovácsi [CT47], Nagykőrös [DT00], Nemesvid [XM75], Piliscsaba [CT37], Piliscsév [CT38], Pilisszentkereszt [CT48], Pilisszentkereszt (Dobogókő) [CT48], Pilisszentlászló [CT48], Pusztavacs [CT82], Répáshuta [DU62], Sajókaza [DU64], Somló-hegy (hill) [-], Sövényháza (recent name = 
Ópusztaszer) [DS25], Szabadszállás [CS69], Szentgotthárd [WN90], Szögliget [DU77], Tihany [YM19], Vajta [CS27].

Acalypta parvula (Fallén, 1807): Eger [DU50], Esztergom [CT39], Répáshuta [DU62], Szendehely [CU50].

Acalypta gracilis (Fieber, 1844): Bükkszenterzsébet [DU32], Cece [CS18], Pócsmegyer [CT58], Salgótarján (Somoskőújfalu) [DU13].

Acalypta musci (Schrank, 1781): Alsószuha [DU65], Bakony (mountains) [-], Bakonybél [YN03], Bélapátfalva [DU52], Bódvarákó [DU87], Dömös [CT39], Eger [DU50], Esztergom [CT39], Jósvafö [DU67], Kelebia [CS91], Kelemér [DU55], Kosd [CT69], Mónosbél [DU52], Nagykovácsi [CT47], Magymaros [CT49], Nemesvita [XM88], Oroszlány [BT96], Pásztó [DU00], Piliscsév [CT38], Pilisszentkereszt [CT48], Pilisszentkereszt (Dobogókő) [CT48], Pilisszentlászló [CT48], Putnok [DU54], Répáshuta [DU62], Sirok [DU30], Sopron [XN18], Szendehely [CU50], Szendrőlád [DU85], Szentendre [CT58], Szögliget [DU77], Tornakápolna [DU76], Vámosatya [FU03].

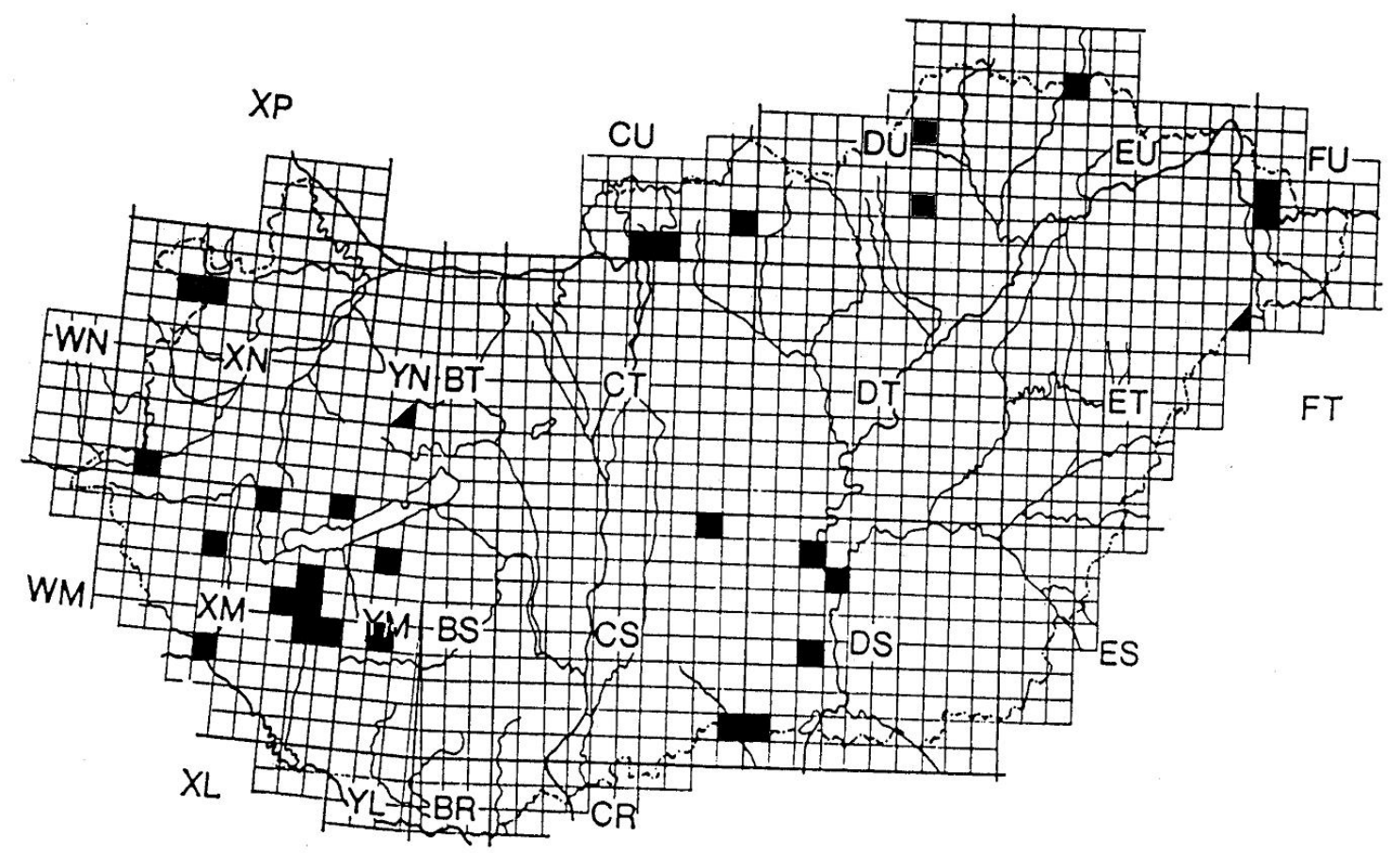

Figure 3. Localities of Acalypta carinata in Hungary. $\boldsymbol{\Lambda}=$ literature data, $\mathbf{\square}=$ new data (partly published in [1] and [32]).

\section{Phenology}

Because of the sporadic and non-quantitative collectings and the aggregative occurrence of the animals, the numbers of species collected in different dates cannot be compared. However, some qualitative establishments can be made based on the presence/absence of the species (Fig. 4).

Very few data are available both on larvae and adults of $A$. platycheila, A. nigrina and $A$. gracilis, therefore, these species are not discussed.

Larvae of $A$. carinata and A. marginata were collected in most months between February and December; however, adults were captured only from May to September or April to July, respectively. The overwintering of these species as larvae (also young and elder ones) is almost certain, however, adult specimens were collected only in summer and early autumn. 

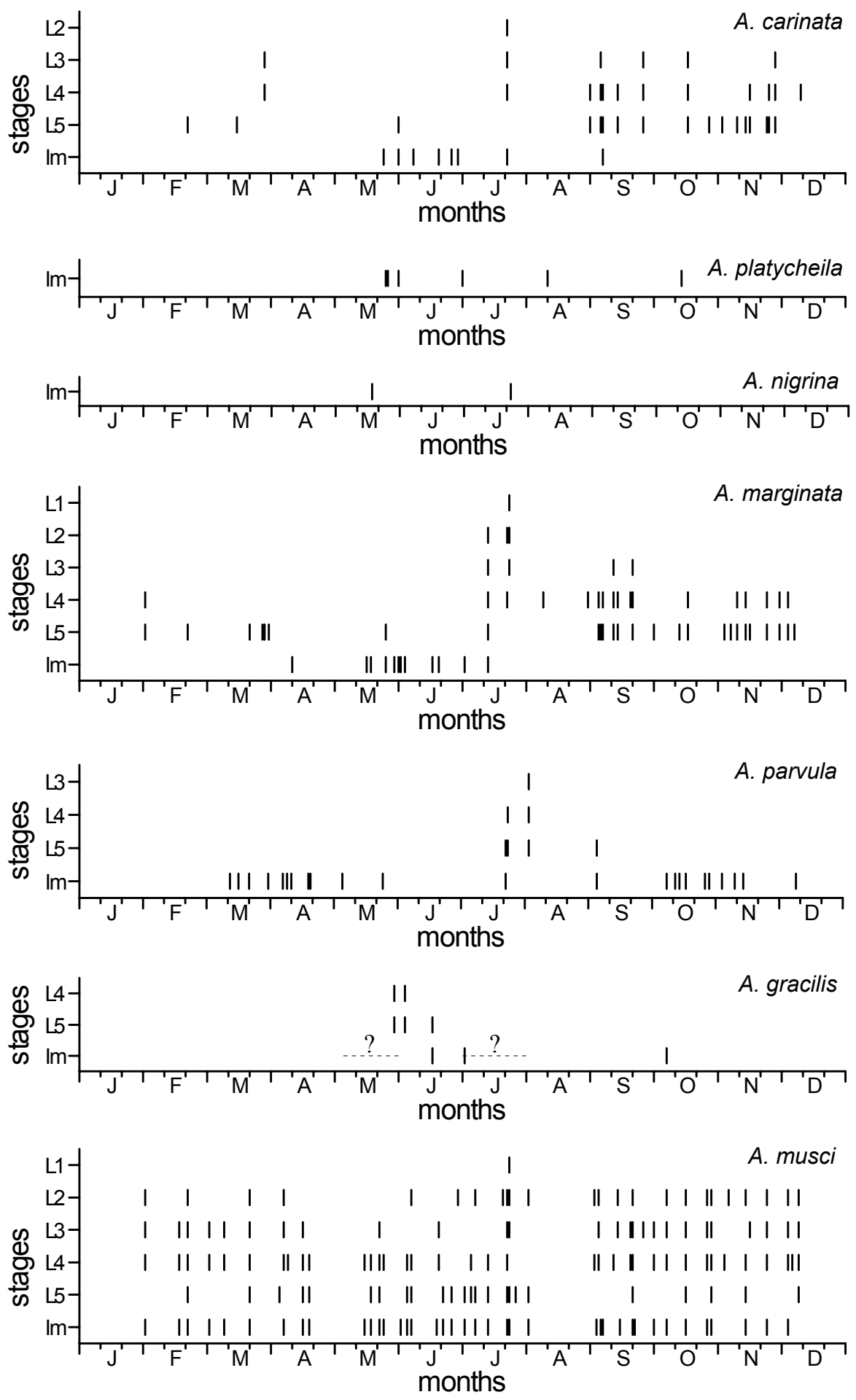

Figure 4. Dates of collection of different species of Acalypta based on many years' data from diverse localities in Hungary. In A. gracilis, '?' means month record only. Im = adults, L1 ...L5 $=1^{\text {st }} \ldots 5^{\text {th }}$ instar larvae.

Adults of A. parvula were collected from March to December, therefore, the species must overwinter as adults. Larvae were collected between July and September; however, because of the few data available, the overwintering in larval stage cannot be excluded. 
Adults and larvae of $A$. musci were collected in great number throughout the year, between February and December. The species must overwinter as larvae (young and elder ones also) as well as adults, usually together.

\section{Habitat preference}

The number of Acalypta individuals collected in different plant community groups were examined (Table 2). The examined communities belonging to these groups were published in the previous part of this series of publications [31].

Table 2. The community types examined.

\begin{tabular}{|c|c|}
\hline Community type & Community group \\
\hline A humid treeless communities & $\begin{array}{ll}1 & \text { reed beds and large sedge communities } \\
2 & \text { bogs and acidic fens } \\
3 & \text { humid grassland communities }\end{array}$ \\
\hline B dry grassland communities & 4 steppe and dry calcareous grasslands \\
\hline $\begin{array}{l}\text { C humid and riverine woodland } \\
\text { communities }\end{array}$ & $\begin{array}{c}5 \text { alder swamp woods } \\
6 \text { riparian willow formations, stream ash-alder woods } \\
\quad \text { and other riverine forests } \\
\end{array}$ \\
\hline $\begin{array}{l}\text { mesophilous and relatively dry } \\
\text { deciduous and coniferous forests }\end{array}$ & $\begin{array}{l}7 \text { Medio-European beech forests and oak-hornbeam forests } \\
8 \text { dry and mesophilous oak woods, mixed forests } \\
\text { and deciduous thickets } \\
9 \text { coniferous forests }\end{array}$ \\
\hline
\end{tabular}

The species occurring in greatest number in humid treeless communities (cenosis groups 1-3) was A carinata; this species gave $90.0 \%$ of the total Acalypta specimens collected in such habitats. The species was extracted mostly from materials collected in Caricetum elatae, often in great number. In this type of communities, also $A$. platycheila, A. marginata and A. musci occurred but in far lower number.

In steppe and dry grassland communities (cenosis group 4), no species occurred in high number. Acalypta marginata and A. parvula were the species collected in greatest number of individuals; A. carinata, A. gracilis and A. musci occurred only in low number.

In humid and riverine woodland communities (cenosis groups 5-6), the species captured in greatest number was $A$. carinata. This species occurred in especially high number in Querco-Ulmetum. Also many specimens of $A$. musci were found in this community type, most of them in stream ash-alder woods. Acalypta platycheila and $A$. marginata occurred in very low number of individuals.

Each species except the extremely rare A. nigrina were collected in the group of mesophilous and relatively dry deciduous and coniferous forests (cenosis groups 7-9). (The five specimens of $A$. nigrina, collected in unrecorded community, are originated most probably also from deciduous forest.) The great majority $(72.8 \%)$ of the individuals collected in such woodland communities belongs to $A$. musci; the species $A$. carinata, A. marginata, A. parvula and $A$. gracilis occurred in far less number, and only a single specimen of $A$. platycheila was collected.

Regarding the individual species, $A$. carinata was found in all groups of cenoses investigated, except in humid grasslands. However, latter absence may be due to the low number of samples collected in such communities. The species was found to be the dominant Acalypta species in large sedge communities (particularly in Caricetum) and 
riverine woodland communities (particularly in Querco-Ulmetum). The species seems to tolerate a wide range of habitats, but shows definite preference to hygrophilous ones. The wooded or treeless character of the plant community seems to be a secondary condition since it was collected in great number in both types of habitats, but its real importance is difficult to establish because of the relatively low number of samples taken.

Virtually nothing can be established on the habitat preference of A. platycheila and $A$. nigrina because of the very few specimens available. However, it should be mentioned, that $A$. platycheila was collected mostly in the community types in which $A$. carinata was found to occur in relatively great number. In the southeastern part of Hungary, at Csaroda, this species was extracted at the same locality in two different occasions accompanied by $A$. carinata. In these occasions, the extracted substrata were mosses collected in Dryopteridi-Alnetum.

Acalypta marginata was found in relatively low number but in diverse plant communities. It was collected also in humid and more or less dry, woodless or wooded places; therefore, the species must tolerate a wide range of community types. However, it seems to prefer relatively dry habitats. Acalypta parvula and A. gracilis were found mostly in similar communities as A. marginata but in lower number; A. gracilis was also collected accompanied with $A$. marginata in some occasions in dry grassland communities, dry sand steppe oak woods (Festuco-Quercetum) and even pine woods planted on sandy soil.

The species collected in greatest number of individuals, $A$. musci, was also found to occur in most of the examined community types. It was captured in great number in Medio-European beech and oak-hornbeam forests (particularly in Querco-Carpinetum) as well as in dry and mesophilous oak woods, mixed forests and deciduous thickets (particularly in Tilio-Fraxinetum). Also a considerable amount of it was collected in riverine forests, but only a few specimens were found in woodless habitats.

The similarities of the species collected in different plant communities were studied with principal coordinate analysis (PCoA) and hierarchical clustering (both with Horn index). Because of the low number of data on some communities, for this analysis, the variables used were major coenosis types summarized from coenosis groups 1-9 (Table 2 ). The number of specimens collected in each major coenosis types was standardized with the total number of samples taken in that type.

In the pattern obtained (Figs. 5-6), A. marginata, A. parvula and A. gracilis show close resemblance and segregate significantly from the other species. This is undoubtedly due to the fact that each of them was collected in greatest relative number in dry grasslands, while the number of other species was the lowest in this type of communities. The segregation of $A$. musci from $A$. carinata and $A$. platycheila can be explained by the fact that $A$. $m u s c i$ had a high relative number in the group of mesophilous and relatively dry deciduous and coniferous forests besides low relative number in humid treeless communities, while this relation was inverse in case of the other two species. The PCoA and hierarchical clustering gave highly similar results.

The diversity conditions of the summarized data of the different plant community types were examined by Rényi's method (Fig. 7). It can be established that - except at the very low values of scale parameter - the assemblage of the humid treeless communities is the least diverse, with a very strong dominance of $A$. carinata; the 


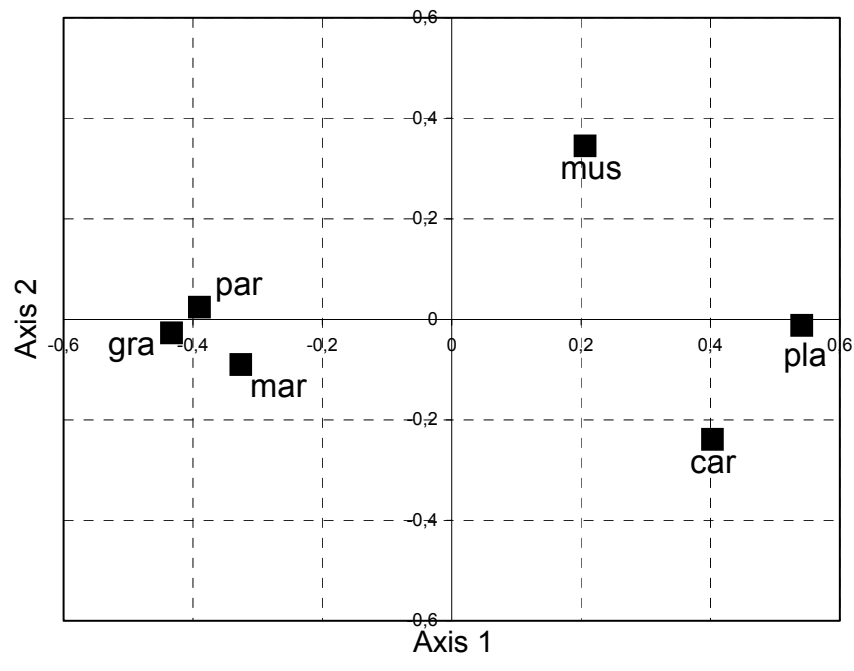

5

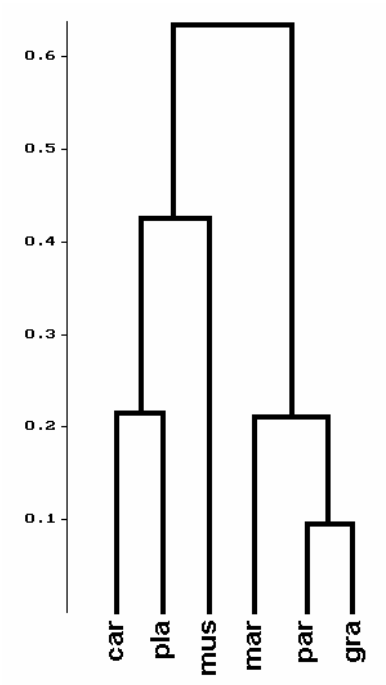

6

Figures 5-6. 5: Similarity pattern (PCOA, Horn index) and 6: similarities (hierarchical clustering, single ling, Horn index as distance) of the species collected in different plant communities

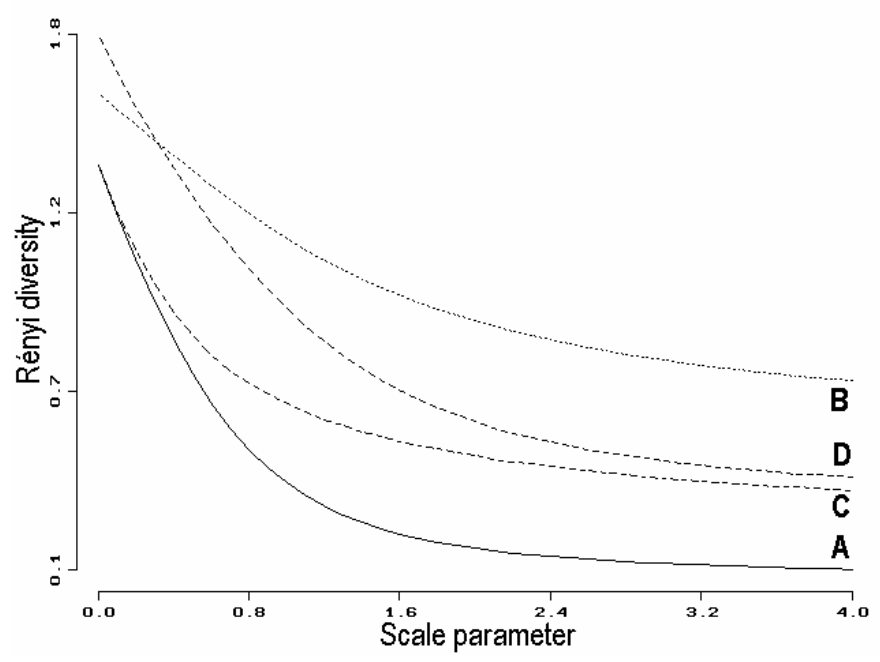

Figure 7. Diversity profiles of the summarized Acalypta samples taken in different plant community types. $A=$ humid treeless communities; $B=d r y$ grassland communities; $C=$ humid and riverine woodland communities; $D=$ mesophilous and relatively dry deciduous and coniferous forests.

assemblage of the humid and riverine woodlands is more diverse, with a dominance of $A$. carinata and a relatively great number of $A$. musci; the assemblage of the mesophilous and relatively dry deciduous and coniferous forests is more diverse than the previousones with a dominance of $A$. musci and the presence of $A$. carinata, $A$. platycheila, A. marginata, A. parvula, A. gracilis; finally, the assemblage of the dry grassland communities is the most diverse, with greatest number of $A$. marginata and $A$. parvula and a smaller number of $A$. carinata, A. gracilis and A. musci. 


\section{Substrate preference}

All species were extracted in greatest number of specimens from different mosses. Relatively great amount of $A$. marginata and $A$. parvula were taken from tussocks; the former species was collected in the greatest relative number in this type of substrata. The two most abundant species, A. carinata and $A$. musci were also collected in considerable amount from leaf litter. Surprisingly, a few specimens of $A$. carinata, $A$. platycheila, A. marginata, A. parvula and A. musci were taken also from soil.

\section{Number of individuals pro sample}

Regarding the adult specimens, most species were found only in very low number pro extracted sample. Even A. marginata, from which relatively great series were collected, was extracted always in low number - maximally four - pro sample. On the other hand, the relatively seldom collected A. parvula was found to constitute groups of more than five animals in $10.3 \%$ of the cases (17 on one occasion). The frequently captured $A$. musci was also often found in relative large groups, on one occasion 20 adults were extracted from a sample.

Regarding the larvae, $A$. marginata was found to constitute groups of more than five specimens in $19.5 \%$ of the cases (35 on one occasion). Acalypta carinata and A. musci was found in the greatest number pro sample; more than five specimens of larvae, usually together with adults, were collected in $40.3 \%$ and $30.3 \%$ of the cases, respectively. The greatest number of larvae extracted from the same sample was 37 in the case of $A$. musci (together with one adult), 101 in $A$. carinata.

\section{Materials taken by pitfall traps in the Kiskunság National Park}

\section{Species composition}

In the territory examined, only A. marginata and A. gracilis were found, both in great number of individuals.

\section{Seasonal patterns of the activity}

The number of adult individuals of $A$. marginata and $A$. gracilis collected with pitfall traps at Bugac during four different years are figured in Fig. 8. In each year, specimens were captured in greatest number during May and June; unfortunately, there are no pitfall trap data available before May. Ovipositing females were captured in great number with pitfall traps placed out between $3^{\text {rd }}$ June and $1^{\text {st }}$ July 1982. In the years 1980 and 1982, a second peak of activity of $A$. gracilis, with far less number of individuals, could also be observed around August. A few specimens of this species were collected even in October and November; however, no specimens of $A$. marginata were captured after middle of August. The number of captured individuals differed highly in the different years; the total number was smaller in the years 1979 and 1980 than in the years 1981 and 1982. Regarding the two latter years, A. gracilis was captured in far greater number than $A$. marginata in 1981; this ratio was inverse in the year 1982.

In the year 1982, A. marginata larvae were collected in great number. The number of larvae and adults of $A$. gracilis are figured in Fig. 9. The $2^{\text {nd }}-5^{\text {th }}$ instar larvae appeared before the adults, they were collected in May and June. The increase of the activity from younger to elder instars was observed. During the same year, the activity of A. gracilis larvae was very low. 

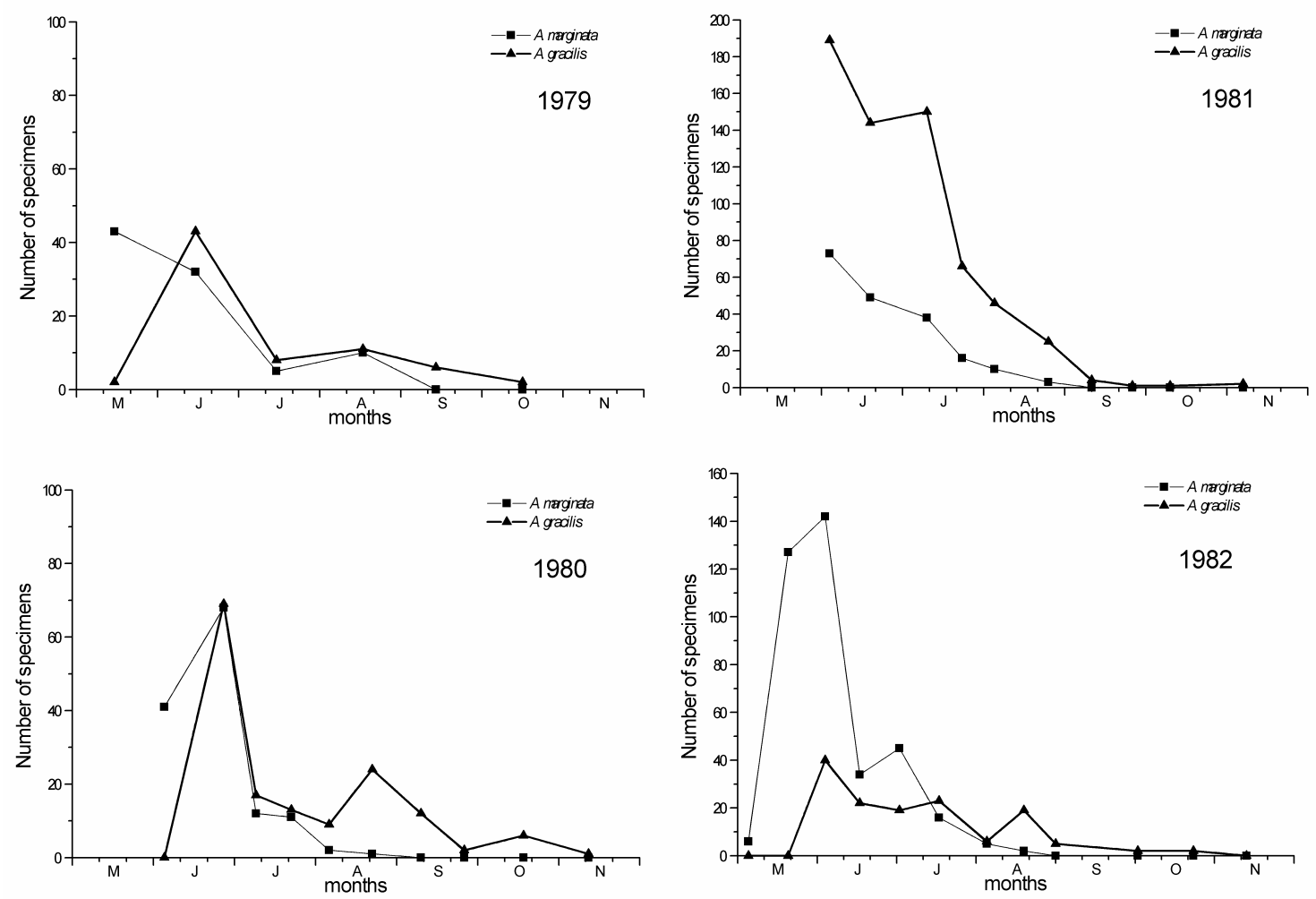

Figure 8. The number of adult individuals of Acalypta marginata and A. gracilis collected with pitfall traps at Bugac during four different years.

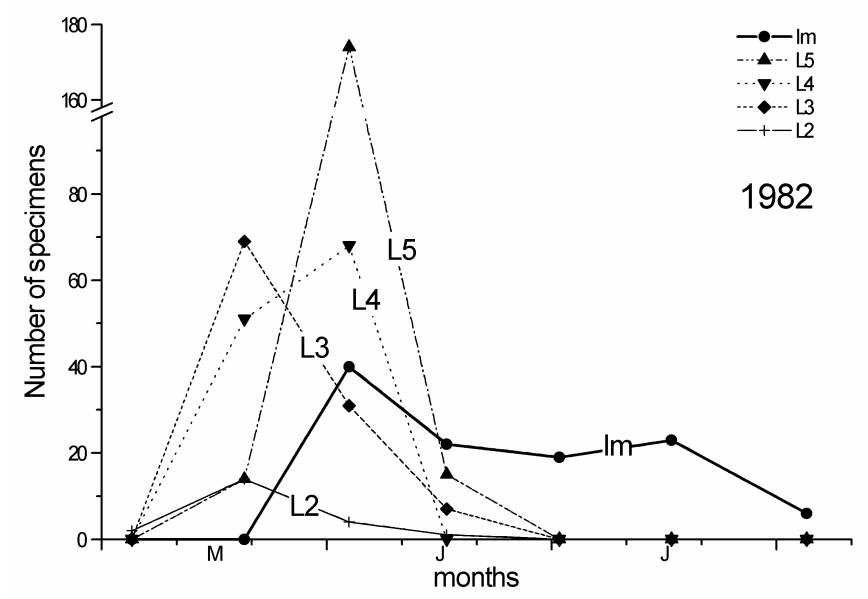

Figure 9. The number of larvae and adult individuals of Acalypta gracilis collected with pitfall traps at Bugac between May and early August 1982.

\section{Microhabitat preference}

Considering the relative number of the adult individuals of $A$. gracilis and $A$. marginata collected in patches colonized by different vegetation (Fig. 10), the following observations can be made. In each year, much less specimens of both species occurred in the dune-slack purple moorgrass meadow patches than in the other two 
xerophilous grassland ones. In case of $A$. gracilis, the greatest number was captured in the traps placed out in the Pannonic dune open grassland patches. In case of $A$. marginata, the difference between the number of individuals captured in the Pannonic dune open grassland and Pannonic sand puszta patches was small; in the years 1979 and 1982, the total number of individuals was somewhat higher in the former one, while in 1980 and 1981, it was higher in the latter one.

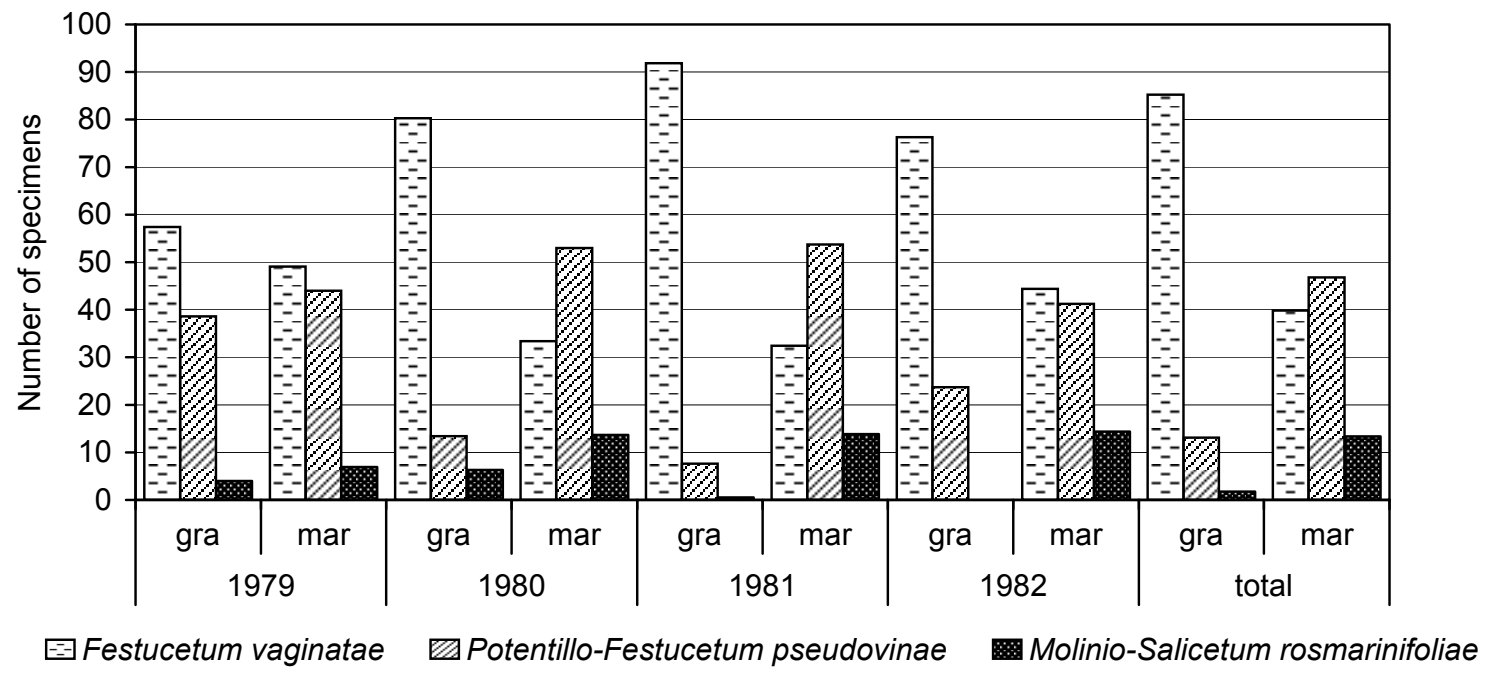

Figure 10. Percental ratio of the total number of adult individuals of Acalypta gracilis and A. marginata collected with pitfall traps in different plant communities at Bugac in the years 1979-1982 and the summarized data of the years (total of the specimens taken in all the three communities in one year altogether $=100 \%)$. The numbers of individuals were standardized with the number of traps placed out in each community.

Comparing pitfall trap samples with $\chi^{2}$ test for independence, it can be proved that the number of the samples containing both species is significantly higher than the expected random distribution $(P=0.0036)$. Considering only the samples which contain any of the two species, sharp negative association can be observed: the number of samples containing only one species is significantly higher, that of samples containing both species is significantly lower than the expected random distribution $\left(P=2 \cdot 10^{-77}\right)$. Consequently, the differences between the microhabitat distribution of the two species as described above are significant.

\section{Summary}

Based on many years' sporadic collection data, the numbers of specimens of Acalypta species collected in diverse plant communities in Hungary were compared. Acalypta marginata, A. parvula and A. gracilis occurred in greatest relative number in dry grassland communities, while the number of $A$. musci, A. carinata and $A$. platycheila was the lowest in this type of communities. Acalypta musci had a high relative number in mesophilous and relatively dry deciduous and coniferous forests besides low relative number in humid treeless communities, while this relation was inverse in case of $A$. carinata and $A$. platycheila. In broad outline, these results agree well with the results of collecting experience of previous authors $[26,30]$. 
All species were extracted in greatest number of specimens from different mosses. Acalypta marginata and $A$. parvula were taken relatively frequently from tussocks, $A$. carinata and $A$. musci from leaf litter.

The phenology of $A$. marginata and $A$. gracilis differs highly from that of $A$. carinata and $A$. musci in Austria, discussed by Ressl \& Wagner [35]. According to these authors, A. carinata and A. musci shows two peaks of abundance, the first one in April-May, the second one around August (A. carinata) or October (A. musci). This pattern is similar to that of $A$. parvula in the same country [24]. These species must be univoltine, with copulation in late summer and autumn, oviposition in autumn. The phenology of $A$. nigrina differs from the species above; in Germany, it was observed to be also univoltine, with copulation in June-July, oviposition in July-August [24]. According to our observations, the seasonal pattern of the activity of $A$. marginata is similar to that of the taxonomically very closely related species, A. nigrina, because this species also has a peak of activity in late May and June, but oviposition most probably takes place somewhat earlier, in June and July. It is quite interesting, that - contrasted with the species $A$. marginata and $A$. nigrina - the phenologies of the taxonomically also closely related $A$. gracilis and $A$. parvula differ sharply: in the area examined, the activity of $A$. gracilis showed a temporal pattern similar to $A$. marginata. The numbers of $A$. marginata and $A$. gracilis showed great differences in the different years; in some years, one species occurred in greater number, in other years the other one.

Considering the differences of the relative number of $A$. gracilis and A. marginata captured in patches with different vegetation, the two species show significant differences. Both species occurred in very low number in the dune-slack purple moorgrass meadow, the most humid community of the three. Acalypta gracilis preferred distinctly the Pannonic dune open grassland, the most xerophilous, most exposed community of the three, while A. marginata occurred in almost equal number in this patches as well as in the Pannonic sand puszta. These observations suggest the xerophily of both species; the preference for xerophilous conditions of $A$. gracilis seems to be higher than that of $A$. marginata. This result agrees well with the results of the examination based on many years' collection data.

Acknowledgements. We are very grateful to Dr. K. Dózsa-Farkas for providing Dr I. Loksa's collection, thereby making our investigations possible. Our thanks are also due to Dr. L. Gallé, Dr. Gy. Györffy, Dr. E. Hornung and Dr. L. Móczár as well as to the staff of the Department of Ecology of the University of Szeged for the pitfall trap materials collected at Bugac. We also would like to express our special thanks to the late Dr. I. Loksa (1923-1992), eminent Hungarian zoologist, former head of the Department of Systematic Zoology and Ecology of the Eötvös Loránd University, researcher of many soil-inhabiting invertebrate groups, especially Arachnoidea and Myriapoda. Without his pioneering and assiduous activity on the research of the soil fauna of Hungary it would have been impossible to implement our work.

\section{REFERENCES}

[1] Bakonyi, G., Csölle, C., Fabók, V., Földessy, M., Hufnagel, L., Kondorosy, E., Rédei, D., Tölgyesiné-Nell, T., Varga, I. \& Vásárhelyi, T. (2002): The Heteroptera fauna of the Fertő-Hanság National Park. - In: Mahunka, S. (ed.): The Fauna of the Fertö-Hanság National Park, II: 325-350. Magyar Természettudományi Múzeum, Budapest.

[2] Bakonyi, G. \& Vásárhelyi, T. (1981): Contribution to the Heteroptera fauna of the Hortobágy National Park, I. - In: Mahunka, S. (ed.): The Fauna of the Hortobágy National Park, I: 55-63. Akadémiai Kiadó, Budapest. 
[3] Bakonyi, G. \& Vásárhelyi, T. (1987): The Heteroptera fauna of the Kiskunság National Park. - In: Mahunka, S. (ed.): The Fauna of the Kiskunság National Park, II: 85-106. Akadémiai Kiadó, Budapest.

[4] Bator, A. (1953): Die Heteroptera Nordtirols. I. Tingidae (Netzwanzen). - Beiträge zur Entomologie 3(3): 323-333.

[5] Bodrogközy Gy. \& Farkas, Gy. (1981): Correlations between vegetation and hydroecology in the sandy grasslands of Kiskunság Natonal Park. - Acta Biologica Szegediensis 27 (1-4): 33-53.

[6] Borhidi, A. (2003): Magyarország növénytársulásai. [The plant communities of Hungary.] Akadémiai Kiadó, Budapest, 1-610. [in Hungarian]

[7] Butler, A.G. (1923): Biology of the British Hemiptera-Heteroptera. Witherby, London, viii+682 pp.

[8] Cobben, R.H. (1953): Bemerkungen zur Lebensweise einiger Hollandischen Wanzen (Hemiptera-Heteroptera). - Tijdschrift voor Entomologie 96(3): 169-198.

[9] Gallé, L., Györffy, Gy., Körmöczi, L., Szőnyi, G. \& Harmat, B. (1987): Különböző közösségtípusok élőhely heterogenitás indikációja homokpusztai gyepen. - In: Tudomány-Természet-Társadalom. Környezettudományi Kutatások az MTA területi Akadémiai Bizottságainál I: 230-271. Budapest.

[10] Golub, V.B. \& Péricart, J. (1981): Compléments à l'étude taxinomique du groupe d'espèces Acalypta carinata-A. platycheila [Hem. Tingidae]. - L'Entomologiste 37(1): 27-32.

[11] Gulde, J. (1921): Die Wanzen (Hemiptera-Heteroptera) der Umgebung von Frankfurt am Main und des Mainzer Beckens. - Abhandlungen der Senckenbergischen Naturforschenden Gesellschaft 37(4): 1-175.

[12] Gulde, J. (1938): Die Wanzen Mitteleuropas. Hemiptera Heteroptera Mitteleuropas. VI. Teil (Piesmidae, Tingitidae, Aradidae), pp. 225-377. Verlag Otto H. Wrede, Frankfurt

[13] Harmat, B. (1984): Angaben zur Kenntnis der Heteropteren-Fauna von SandsteppenGräser I. - Folia entomologica hungarica 45(2): 97-101.

[14] Hedicke, H. \& Michalk, O. (1934): Bemerkungen über einige Heteropteren von Bellichen und seiner Umgebung. - Markische Tierwelt 1(1): 26-34.

[15] Horváth, G. (1881): Hemiptera nova vel minus cognita. I. - Természetrajzi Füzetek 5: $39-42,217-225$.

[16] Horváth, G. (1900): Ordo Hemiptera. - In: Paszlavszky, J. (ed.): A Magyar Birodalom Állatvilága (Fauna Regni Hungariae), III. (Arthropoda). A K. M. Természettudományi Társulat, Budapest, $72 \mathrm{pp}$.

[17] Horváth, G. (1906): Synopsis Tingitidarum Regionis palaearcticae. - Annales historiconaturales Musei nationalis Hungarici 4: 1-117.

[18] Jordan, K.H.C. (1940): Die Heteropterenfauna des Dümmers und seiner Moore. Stettiner Entomologische Zeitung 101(3): 34-41.

[19] Jordan, K.H.C. (1963): Die Heteropterenfaua Sachsens. - Faunistische Abhandlungen, Staatliches Museum für Tierkunde in Dresden 1: 1-68.

[20] [Kiritshenko, A.N.] Кириченко, А.Н. (1951): Настоящие полужесткокрылые Европейской части СССР (Hemiptera). Определитель и библиография. [True bugs of the European part of the USSR (Hemiptera). Key and bibliography.] - In: Определители по фауне CCCP [Keys to the fauna of the USSR] 42: 1-423. Moscow, Leningrad. [in Russian]

[21] Kondorosy, E. (1999): Checklist of the Hungarian bug fauna (Heteroptera). - Folia entomologica hungarica 60: 125-152.

[22] Körmöczi, L. (1983): Correlations between the zonation of sandy grassland and the physico-chemical condition of their soil in Bugac. - Acta Biologica Szegediensis 29: 117127.

[23] Körmöczi, L., Bodrogközy, Gy. \& Horváth, I. (1981): Investigation of biological production and bioclimate of sandy grassland in Bugac - Acta Biologica Szegediensis 27(1-4): 55-69. 
[24] Melber, A. (1989): Raum-zeitliches Verteilungsmuster zweier syntoper Acalypta-Arten (Heteroptera, Tingidae) in nordwestdeutschen Calluna-Heiden. - Zoologisches Jahrbuch für Systematik 116: 151-159.

[25] Móczár, L., Gallé, L. \& Hornung, E. (1980): Complex ecological investigations in a sandy soil grassland: aims and general methodology. - Acta Biologica Szegediensis 26: 161-164.

[26] Péricart, J. (1983): Hémiptères Tingidae Euro-Méditerranéens. In: Faune de France, France et régions limitrophes, 69: 1-618. Fédération Française des Sociétés de Sciences Naturelles, Paris.

[27] Péricart, J. \& Golub, V.B. (1996): Superfamily Tingoidea Laporte, 1832. - In: Aukema, B. \& Rieger, Ch. (eds): Catalogue of the Heteroptera of the Palaearctic Region. Vol. 2. Cimicomorpha I. The Netherlands Entomological Society, Amsterdam, pp. 3-78.

[28] Podani, J. (1993a): SYN-TAX version 5.0 Users Guide. Scientia, Budapest, 104 pp.

[29] Podani, J. (1993b): SYN-TAX. Computer programs for multivariate data analysis in ecology and systematics. - Abstracta Botanica 17: 289-302.

[30] [Putshkov, V.G.] Пучков, В.Г. (1974): Беритиди, червоноклопи, пиезматиди, підкорники і тингіди. [Berytidae, Pyrrhocoridae, Piesmatidae, Aradidae and Tingidae.] - In: Фауна України [Fauna of the Ukraine], 21(4): 1-332. Kiev. [in Ukrainian]

[31] Rédei, D., Gaál, M. \& Hufnagel, L. (2003): Spatial and temporal patterns of true bug assemblages extracted with Berlese funnels. Data to the knowledge on the ground-living Heteroptera of Hungary, № 2. - Applied Ecology and Environmental Research 1(1-2): $115-142$.

[32] Rédei, D. \& Hufnagel, L. (2003a): The species composition of true bug assemblages extracted with Berlese funnels. Data to the knowledge on the ground-living Heteroptera of Hungary, № 1. - Applied Ecology and Environmental Research 1(1-2): 93-113.

[33] Rédei, D. \& Hufnagel, L. (2003b): Adatok a Dunántúli-középhegység talajlakó poloskafaunájának ismeretéhez (Heteroptera). (Adatok Magyarország talajlakó poloskáinak ismeretéhez I.) [Data to the knowledge on the soil bug fauna of the Hungarian Transdanubian-Mountains (Heteroptera).] - Folia Musei Historico-naturalis Bakonyiensis 20 (2001-2003): 63-76. [in Hungarian, English abstract]

[34] Rédei, D. \& Hufnagel, L. (2003c): Adatok az Északi-középhegység talajlakó poloskafaunájának ismeretéhez (Heteroptera). (Adatok Magyarország talajlakó poloskáinak ismeretéhez II.) [Data to the knowledge on the soil bug fauna of the Hungarian NorthernMountains (Heteroptera).] - Folia historico naturalia Musei Matraensis 27: 81-89. [in Hungarian, English abstract]

[35] Ressl, F. \& Wagner, E. (1960): Die Tingidae und Aradidae (Heteroptera) des polit. Bezirkes Scheibbs, Niederösterreich. - Zeitschrift der Arbeitsgemeinschaft österreichischer Entomologen 12(1): 1-18.

[36] [Roshko, G.M.] Рошко, Г.М. (1969): Экологическая характеристика кружевниц (Tingidae, Hemiptera) в Украинских Карпатах. [Ecological characterization of lace bugs (Tingidae, Hemiptera) of Carpathian Ukraine] - In: Вопросы охраны природы Карпат [Questions of nature conservation of the Carpathians], pp. 138-155. Uzhgorod. [in Russian]

[37] Singer, K. (1952): Die Wanzen (Hemiptera-Heteroptera) des unteren Maingebietes von Hanau bis Würzburg mit Einschluß des Spessarts. - Mitteilungen des Naturwissenschaftlichen Museums der Stadt Aschaffenburg (N.S.) 5: 1-128.

[38] Smreczyński, S. (1954): Materiały do fauny pluskwiaków (Hemiptera) Polski. [Data to the Hemiptera fauna of Poland.] - Fragmenta Faunistica 7(1): 1-146. [in Polish, French summary]

[39] Stichel, W. (1960): Wanzenfauna Ost- und Westpreussen. Berlin-Hermsdorf, 80 pp.

[40] Štusák, J. (1957): A contribution to the knowledge of some last nymphal instars of the Czechoslovakian lace bugs (Hemiptera-Heteroptera, Tingidae). - Časopis Československé Společnosti Entomologické 54(2): 132-141. 
[41] Štusák, J. (1958): Zweiter Beitrag zur Kenntnis der Eier der Tingiden (HemipteraHeteroptera, Tingidae). - Časopis Československé Společnosti Entomologické 55(4): 361-371, 1 tabl.

[42] Štusák, J. (1960): New discoveres about nymphs of some tingid bugs (HemipteraHeteroptera, Tingidae). - Časopis Československé Společnosti Entomologické 57(2): $118-128$.

[43] Štusák, J. (1964): The nymphs of Agramma minuta (Horv.), Acalypta gracilis (Fieb.) and Dictyonota tricornis (Schrk.) (Heteroptera, Tingidae). - Časopis Československé Společnosti Entomologické 61(1): 19-24.

[44] Tamanini, L. (1961): Interessanti reperti emitterologici nella Venezia Tridentina (Hemiptera Heteroptera). - Studi Trentini di Scienze Naturali 38(2): 67-130.

[45] Tóthmérész, B. (1993): NuCoSA 1.0. Number Cruncher for Community Studies and other Ecological Applications. - Abstracta Botanica 17: 283-287.

[46] Tóthmérész, B. (1995): Comparison of different methods for diversity ordering. - Journal of Vegetation Science 6: 283-290.

[47] Tóthmérész, B. (1996): NuCoSA: Programcsomag botanikai, zoológiai és ökológiai vizsgálatokhoz. [NuCoSA: a program package for data analysis in botanics, zoology and ecology.] - Synbiologia Hungarica 2(1): 1-84. [in Hungarian]

[48] Vásárhelyi, T. (1974): Új és kevéssé ismert csipkéspoloskák a magyar faunában (Heteroptera: Tingidae). [New and little-known lace bugs in the Hungarian fauna (Heteroptera: Tingidae).] - Folia entomologica hungarica 27(2): 231-234. [in Hungarian, English and German abstract]

[49] Vásárhelyi, T. (1978): Poloskák V.-Heteroptera V. - In: Magyarország Állatvilága (Fauna Hungariae), XVII, 5: 1-76. Akadémiai Kiadó, Budapest. [in Hungarian]

[50] Vásárhelyi, T., Kondorosy, E. \& Bakonyi, G. (1990): The Heteroptera fauna of the Bátorliget Nature Reserves. - In: Mahunka, S. (ed.): The Bátorliget Nature Reserves after forty years, 2: 347-355. Magyar Természettudományi Múzum, Budapest.

[51] Wagner, E. (1952): IV. Contributo alla conoscenza della fauna emitterologica italiana. Bemerkenswerte Tingidae und Reduviidae aus Italien. - Bollettino dell'Associazione Romana di Entomologia 7(2): 13-14.

[52] Wagner, E. (1967): Wanzen oder Heteropteren. II. Cimicomorpha. - In: Die Tierwelt Deutschlands 55: 1-179. 